Çeşm-i Cihan:

Tarih Kültür ve Sanat Araştırmaları E - Dergisi ISSN: 2149-5866 Cilt:5, Sayı:1, s. 140-157, Yaz 2018

Araştırma-İnceleme

DOI: $10.30804 /$ cesmicihan.427535 BARTIN - TÜRKIYE
Bartın Üniversitesi

Bartın ve Yöresi

Tarih - Kültür Araştırmaları

Uygulama ve Araştırma

Merkezi

(BAYTAM)

\title{
ULUSAL GÜVENLİK BAĞLAMINDA KIBRIS: JEOSTRATEJİK/JEOEKONOMİK ÖNEM VE GELIŞMELER
}

\author{
Dr. Pınar AKARÇAY* - Dr. Gökhan AK ${ }^{* *}$
}

Öz: Türkiye, Avrasya'nın tam ortasında birçok küresel etkili bölgesel sorunun içinde yaşayan bir ülkedir. Avrasya'nın Doğu Akdeniz'inde yer alan Kıbrıs da Türkiye için bu anlamda gerek jeostratejik, gerekse jeoekonomik olarak vazgeçilemez bir coğrafi aktördür. Zira Doğu Akdeniz'in tabanının altında, özellikle de Kıbrıs'ın güneyinde mali değeri oldukça yüksek hidrokarbon zenginlikleri bulunduğu iddia edilmektedir. Güney Kıbrıs Rum Yönetimi (GKRY) de, adada GKRY tarafından temsil edilmeyen Kıbrıs Türk halkı ve onun devleti olan Kuzey Kıbrıs Türk Cumhuriyeti (KKTC)'nin mevcudiyetinin hilafına, bu muhtemel zenginliklerden tek başına yararlanmaya çalışmaktadır. Ada çevresindeki zengin deniz-dibi kaynakları ile ortaya çıkan yeni menfaat yumağının, Kıbrıs uyuşmazlığının denize de yayılmasına sebebiyet verdiği aşikârdır. Bu bağlamda çalışmada, ulusal güvenlik bağlamında Kıbrıs Adası'nın önemi, Türkiye'nin Doğu Akdeniz'de deniz güvenliğine katkıları ve Doğu Akdeniz'deki son gelişmelerin Kıbrıs Sorunu'nun çözümüne muhtemel etkileri üzerine bir inceleme ve analiz yapılmıştır.

Anahtar Kelimeler: Kıbrıs, Doğu Akdeniz, Jeostrateji, Jeoekonomi, Ulusal Güvenlik, Deniz Yetki Alanları, Hidrokarbon Kaynakları.

\section{CYPRUS REGARDING NATIONAL SECURITY: GEOSTRATEGIC/GEOECONOMIC IMPORTANCE AND RECENT EVENTS}

Abstract: Turkey, as being just in the middle of Eurasia, is a state which is located in the middle of many regional conflicts that have global effects as well. In this sense, Cyprus island of the Eurasia's eastern Mediterranean is an indispensable geographical actor for Turkey as being both geostrategially and geoeconomically. Thus there are essentially large wealthy hydro-carbon sources under the bottom of sea layer of the Eastern Mediterranean, particularly in the south of the Island. Greek Cypriots has noticed this source first and since its value is really very high, they claimed every possible way to have that underwater source alone. However, they normally disregard the rights of Turkey and Turkish Republic of Northern Cyprus (TRNC) in the region, and they acted alone. The first step towards a resolution of a dispute lies in analyzing all aspects. And Cyprus issue is still a conflict between the parties. However, these possible wealthy sources, on which Greek Cypriots claim sole ownership, will clearly have negative effects on the resolution of the Cyprus issue. Thus, in this study it has been discussed the significance of the Cyprus Island regarding national security, Turkish contributions to the maritime security in the Eastern Med and analyzing of the latest developments so far, on the possible effects of the Cyprus Issue.

Keywords: Cyprus, Eastern Mediterranean, Geostrategy, Geoeconomics, National Security, Maritime Jurisdiction Areas, Hydrocarbon Sources.

\footnotetext{
${ }^{*}$ Uppsala Üniversitesi, Institute for Housing and Urban Research, Misafir Araştırmacı.

** Nişantaşı Üniversitesi, İktisadi, İdari ve Sosyal Bilimler Fakültesi, Uluslararası İlişkiler Bölümü.
} 
"Sağlam bir gelecek inşa etmek için, geçmişi çok iyi bilmek gerekir."

\section{GİRİş}

KKTC Meclis Başkanı Hasan Bozer ${ }^{1}$

Türkiye ve KKTC’nin mavi vatanlarından olan Doğu Akdeniz, her iki ülkenin de üç kadim kıtanın orta yerinde, özellikle Orta Doğu’ya açılan bir deniz kapısıdır. Bu kapıyı da Kıbrıs adası, bir hançer gibi zorlar, ürkütür, hatta tehdit eder. Dolayısıyla, aşk tanrıçası Kipris'in diyarı Kıbrıs, uluslararası ilişkiler dünyasında yırtıcı bir kuştur aslında... Adanın stratejik önemi, özellikle soğuk savaşın ertesinde, uluslararası alanda ve bölgede meydana gelen hızlı politik-ekonomik gelişme ve değişimler nedeniyle daha da artmaktadır.

Bu bağlamda, özellikle, GKRY'nin, İsrail'i de yanına çekerek, Doğu Akdeniz'de sözde Münhasır Ekonomik Bölgesi (MEB)'nde tek taraflı girişimlerle hidrokarbon zenginliklerini arama faaliyetleri gibi uluslararası hukuka aykırı eylemlere kalkışması, Türkiye'nin Kıbrıs özelinde Doğu Akdeniz'e bambaşka bir dikkat, önem ve özen göstermesini gerekli kılmaktadır. Zira bugün Doğu Akdeniz'de yaşanan sondaj krizi ve benzeri sorunların temelinde, GKRY ve Yunanistan'ın Doğu Akdeniz'deki deniz alanlarının hepsini, uluslararası hukuka aykırı olarak sahiplenmek istemeleri yatmaktadır.

Doğu Akdeniz'in tabanının altında mali değeri oldukça yüksek hidrokarbon zenginlikleri bulunmaktadır. Bu da, Güney Kıbrıslı Rumları hayli iştahlandırmakta ve bölgedeki diğer devletlerle deniz yetki sınırlandırmasına yönelik hukuki faaliyetler içerisine girmelerine sebep olmaktadır. Ancak, milletler arası hakkaniyet ve nısfet kuralları uyarınca, GKRY'nin tek başına bu faaliyetlere girişme yetkisi bulunmamaktadır. Adada GKRY tarafından temsil edilmeyen bir başka halk, Kıbrıs Türk halkı ve onun devleti olan Kuzey Kıbrıs Türk Cumhuriyeti (KKTC) mevcuttur.

Dolayısıyla, ada çevresindeki zengin deniz-dibi kaynakları ile ortaya çıkan yeni menfaat yumağının, Kıbrıs uyuşmazlığının denize de yayılmasına sebebiyet verdiği aşikârdır. Bu bağlamda, bu çalışmada, öncelikle Kıbrıs Adası'nın ulusal güvenlik bağlamında jeopolitik ve jeostratejik önemi ortaya konulacak, müteakiben Türkiye'nin bu bağlamda Doğu Akdeniz'de deniz güvenliğine yaptığı katkılar ele alınacak ve son olarak da Doğu Akdeniz'deki sualtı zenginliklerine ilikin son gelişmeler incelenecek ve bu zenginliklerden tek taraflı tasarruflarla yararlanmaya çalışan Güney Kıbrıslı Rumların, Kıbrıs görüşmelerinde takınabileceği yeni tavır ve bu çerçevede Rumların daha uzlaşmaz olup olmayacağı temelinde, gelişmelerin Kıbrıs Sorunu'nda çözümüne muhtemel etkileri üzerine bir inceleme ve analiz yapılacaktır.

\footnotetext{
${ }^{1}$ KKTC Cumhuriyet Meclisi Başkanı Hasan Bozer'in, Rumlar tarafından Taşkent'te 15 Ağustos 1974 günü evlerinden toplanarak katledilen Taşkent Şehidi 83 Kıbrıs Türk için Taşkent Şehitler Anıtı'nda 2010 yılında icra edilen anma töreninde yaptı̆̆ı konuşmadan alınmıştır.
} 


\section{1. "MAVI VATAN" KAVRAMI}

Ulusal güvenlik açısından Kıbrıs Adası'nın jeopolitik ve jeostratejik önemini iyi kavrayabilmek için, önce "Mavi Vatan" olarak adlandırabilecek yeni bir kavrama dikkat çekmek istiyoruz. Zira Vatan gerçeği, bünyesinde pek dikkat edilmeyen, pek önem verilmeyen, ama çok değişik ve bir o kadar da önemli başka bir pencere içermektedir. Bu göz ardı edilen pencere, kendi içerisinde eski bir soruya yeni bir perspektif barındırmaktadır. Bu bağlamda, öncelikle "Vatan nedir, neresidir?” sorusu sorulduğunda, çoğunlukla devletlerin karasal ülkelerinin akla geldiği yadsınamaz bir gerçektir. Hâlbuki bu, özellikle uluslararası ilişkiler/politika çalışanları için önemli bir yanılsamadır. Çünkü bu vatan zahiridir; yani vatan, sadece karasal mekânlar değildir. Ülkelerin iç suları, karasuları, bitişik bölgeleri, kıta sahanlıkları, münhasır ekonomik bölgeleri (MEB) de ve hatta bunların üzerindeki hava sahaları da vatandır. Bu bölgeler "Mavi Vatan" olarak adlandırılabilir.

$\mathrm{Bu}$ kavrama açıklık getirilmek istenirse; bilindiği üzere, uluslararası hukuka göre bir devletin ülkesi kara, deniz ve hava ülkelerinden oluşmaktadır. Örneğin Türkiye'nin kara ülkesi, klasik olarak tüm karasal coğrafi alanlarıdır. Ancak, deniz ülkesi ve hava ülkesi çok değişik ve ilginçtir. Uluslararası hukukun mekânsal kurallarına göre, uluslararası deniz ve hava alanlarını oluşturmakla birlikte, devletler, kıyı devleti olarak deniz ve hava ülkelerinde de belirli birtakım egemen haklara sahiptir. ${ }^{2}$ Devletlerin çeşitli egemenlik gösterileri yapabildiği, uygulayabildiği bu deniz ve hava sahaları Mavi Vatan'dır. İşte, bu mavi vatanlardan biri olan Doğu Akdeniz ve Kıbrıs Adası, Türkiye'nin Akdeniz'e, Batı'ya, Güney'e açılan bir hayat alanıdır adeta...³ Doğu Akdeniz, Türkiye için çok önemli bir coğrafyadır. Bu bölge, Türkiye'nin Orta Doğu'ya açlan bir deniz kapısıdır ve bu kapıyı da Kıbrıs Adası bir hançer misali zorlar, ürkütür, hatta tehdit eder. Güzel afroditin diyarı, uluslararası ilişkiler dünyasında yırtıcı bir kuştur aslında... İşte bu yüzden Kıbrıs, Türkiye'nin ellerinden uçmaması ve her daim avucunun içerisinde tutulması gereken bir şahin gibidir.

\section{DOĞU AKDENIZ İLE KIBRIS'IN JEOSTRATEJİK VE JEOEKONOMİK ÖNEMİ}

Adını, "kına çiçeği” olarak bilinen Kypros, mitolojide Kiniros’un kızı, aşk tanrıçası Kipris veya bakır anlamındaki Latince Cuprum kelimesinden aldığı ileri sürülen Kıbrıs Adası, tarihin her döneminde uluslararası kamuoyunun ilgi alanında olmuştur (Hill 1949: 1.). Kıbrıs Adası,

\footnotetext{
${ }^{2}$ Konuyla ilgili ayrıntı için bkz. (Pazarcı 2009: 233-299.)

${ }^{3}$ Mustafa Kemal, "Ordular! İlk Hedefiniz Akdeniz'dir! İleri!..." emrini verdikten sonra, Türk ordusunun işgalci Yunan ordusunu Anadolu'dan atmak üzere neden İzmir'e yöneldiği ilginç bir konudur. Bizim yorumumuz şöyledir: 16 ve 17. yy. Avrupa menșeli bazı haritalarda, bugün "Ege Denizi (Aegean Sea)" olarak adlandırılan deniz, Fransızca "Mer Blanche (yani Beyaz Deniz=Ak Deniz) olarak tanımlanmakta ve yazılmaktaydı. Bugünkü Akdeniz ise, Mer Méditerranée olarak tanımlanmaktaydı. Mustafa Kemal, Adalar Denizi'nin daha önceki yüzyıllarda böyle adlandırıldığını çok iyi biliyordu ve bu nedenle, Türk süvarilerine İzmir'i işaret ederken “Ordular! İlk Hedefiniz Akdeniz'dir! İleri!...” emrini vermiști.
} 
9251 km2 yüzölçümü ile (Atan 1986: 56.) Doğu Akdeniz'in en büyük, Sicilya ve Sardunya'dan sonra da Akdeniz'in üçüncü büyük adası olup, çok eski, bu itibarla çok zengin bir tarihe sahiptir.

Kıbrıs, Doğu Akdeniz'de jeopolitik önemine bağlı olarak Avrupa, Asya ve Afrika kıtaları arasında kilit noktadadır. Bu üç kadim kıta arasında kilit nokta olan Kıbrıs; Fenikeliler, Egeliler ve Frekler adaya zaman zaman yerleşmiş olsalar da, etnik çoğunluğunu Anadolu insanının oluşturduğu ve özellikle 1571 yılından Birinci Dünya Savaşı'na kadar olan sürede Anadolu çiftçisi ve zanaatkârlarının göç ettiği bir adadır. Çeşitli uygarlıkların doğup kaynaştığı Akdeniz'in doğusunda çok önemli geçiş yolları üzerinde ve bunlara hâkim bir mevkide bulunan Kıbrıs Adası'nın tarihi Taş Devrine kadar uzanmakla beraber, coğrafi, kültürel, folklorik değerler göz önüne alınınca ada Anadolu'nun bir parçasıdır (Alasya 1964: 13.).

Doğu Akdeniz'de bulunan Ada, aslında tüm Akdeniz'in jeopolitiğinde yadsınamaz bir stratejik öneme sahiptir. Zira adanın stratejik değeri önemini gerçekte Akdeniz'in stratejik değerinden alır. Akdeniz'in bugün günlük gemi trafiği günde yaklaşık 4000 gemidir. Bu aslında tüm dünya gemi trafiğinin hemen hemen yarısıdır. Akdeniz'deki bu günlük 4000 geminin de yarısından çoğunu tankerler oluşturmaktadır. Bu gemi trafiği, gemilerden oluşan ve birçok kolu olan geniş bir ırmak misali Akdeniz'de özellikle batı-doğu istikametinde akar, durur (Keser 2007: 139.).

NATO’nun “choke-point” diye adlandırdığı ‘düğüm noktaları'ndan en hayatileri Akdeniz'de yer alır: Cebelitarık Boğazı, Sicilya Kanalı, Türk Boğazları ve Süveyş Kanalı. Bu dar deniz geçitlerini de kullanan ve enerji gereksinimi nedeniyle her geçen gün artan yoğun gemi trafiği, doğal olarak Akdeniz'i stratejik yönden daha da önemli bir duruma getirmiștir (Parker 1962: 9.). Nitekim Armaoğlu'na (1983: 5.) göre Kıbrıs, bir 'ada' olarak dahi, Akdeniz'de söz konusu geçitler ve boğazlar kadar stratejik bir geçittir; “Bir kapalı deniz görünümü arz eden Akdeniz'in jeopolitik ve jeostratejik yapısında iki temel unsur vardır. Bunlar, Akdeniz'in stratejik kapıları ve stratejik adalardır." Armaoğlu, aynı makalesinde; “Avrupa, Asya, Afrika'yı birleştiren Akdeniz'in kapıları olarak Cebel-ü Tarık Boğazı, Süveyş Kanalı, Çanakkale ve İstanbul Boğazlarını; stratejik adaları olarak da Malta, Girit ve Kıbrıs'ı işaret eder." (Akt. Atun 2011: 6.)

Ayrıca Akdeniz, Orta Doğu'ya ve Doğu Afrika'ya yakınlığı dolayısıyla, ABD’nin Irak'a müdahalelerinde, Somali operasyonlarında, diğer deyişle Orta Doğu'ya yönelik tüm operasyonlardan görüldüğü üzere, gerek ekonomik yönden, gerek bir gerginlik durumunda veya çatışma halinde stratejik kıta intikalleri yönünden daha da önem kazanmıștır. Buna paralel olarak, Kıbrıs, Türkiye'nin bölgedeki deniz ve hava sahaları alaka ve menfaatleri için hayatidir. Zira bugün adada ihdas edilen deniz ve hava üsleri vasıtasıyla, Kıbrıs'ın bütün çevresi etki ve kontrol altına alınabilmektedir. İlaveten, gelişen teknoloji ile Kıbrıs elektronik dinleme, izleme ve kontrol sistemlerinin de merkezi konumundadır (Torumtay 1998: 15-21.). 
Dolayısıyla Akdeniz'in Sicilya ve Sardunya'dan sonra üçüncü büyük adası olan Kıbrıs, böylesine önemli, aktif ve stratejik değeri olan bir denizin doğusunda, Doğu Akdeniz'de, gerek deniz, gerek havayollarını kontrol edebilen ve hiçbir zaman batmayacak bir uçak gemisidir adeta... Stratejik açıdan büyük önemi olan adanın son yıllarda uluslararası düzeyde jeopolitik ve jeoekonomik önemi giderek daha belirgin bir hal almaya başlamıştır. Nitekim adanın Türkiye açısından jeostratejik değer ve önemini onlarca yıl öncesinden gören Atatürk, Akdeniz bölgesinde 1930'larda gerçekleştirilen askeri manevralarda subaylara, “Türkiye'nin yeniden işgal edildiğini ve Türk kuvvetlerinin sadece bu bölgede mukavemet ettiğini farz edelim. İkmal yollarımız ve imkânlarımız nelerdir?" șeklindeki sorusuna tatmin edici bir yanıt alınmaması üzerine, haritada Kıbrıs'ı göstererek, "Efendiler, Kıbrıs düşman elinde bulunduğu sürece, bu bölgenin ikmal yolları tıkanmıştır. Kıbrıs'a dikkat ediniz. Bu ada bizim için önemlidir." sözleri ile mevcut stratejik durumu ortaya koymuştur. Bugün KKTC'nin bağımsız ve egemen bir devlet olarak varlığının devamı ve Türkiye ile özel ilişkilerinin stratejik önemine, daha o günlerde dikkat çekmiştir (Alasya 1981: 55.).

Mısır ve Doğu Akdeniz ticaret yolları üzerinde yer alması, tarihin bilinen ilk devirlerinden itibaren Kıbrıs'ın önem kazanması ve bu önemin sürekli olması neticesini doğurmuştur. Kıbrıs adası tarih boyunca bölgede etkin durumda olan ve Orta Doğu'yu kontrol altında tutmak isteyen başat güçlerin cazibe merkezi olmuştur. Jeolojik dönemin ikinci ve üçüncü zamanlarında bir çöküntü neticesinde Mersin-İskenderun bölgesinden ayrılıp bir ada haline gelen ve Anadolu'nun doğal bir uzantısı olan Kıbrıs'ın ilk sakinleri Anadolu'dan gelmiştir. Ada kuzeyi ve Karpas yarımadasında gün yüzüne çıkartılan Neolitik devir yerleşim yerlerinden elde edilen buluntular sayesinde, Ada'da M.Ö. 4000 yılından itibaren beşeriyet izine rastlanmıştır. Nitekim tarih boyunca, Truva, Mısır, Hitit, Fenike, Asur, Pers, Makedonya, Roma, Bizans, Araplar, Tapınak Şövalyeleri, Ceneviz, Venedik gibi birçok farklı medeniyet arasında el değiştiren Kıbrıs'ı Osmanlılar 1571 yılında Venediklilerden ele geçirmişleridir. Ada, 1571'den 1878'de Büyük Britanya Krallığı'na kiralanana kadar Osmanlı idaresinde kalmıştır. Birinci Dünya Savaşı sırasında İngiliz Hükümeti, Osmanlıların Almanya safında savaşa girmesine karşılık, 1914'te adayı tek yanlı olarak ilhak etmiştir. Ada, 1923 Lozan Konferansı'nda resmen İngiltere'ye bırakılmış ve bu durum 1960'a kadar devam etmiştir.

352 sene bilfiil Türk egemenliğinde kalan Ada'nın, tarihin hiçbir döneminde Kıbrıs'la ilişkisi olmamış bugünkü Yunan devletinin Ada'ya ilgisi, kendisini Bizans’ın varisi olarak görmesinden ve Megali İdea (Büyük Ülkü)'dan kaynaklanmaktadır (Keser 2012: 313.). Zira Bizans döneminde, Bizans'ın resmi dil olarak Yunancayı, resmi din olarak Ortodoks Hıristiyanlığı kabul etmesi ve bunu zorla Kıbrıs'taki kimlik bunalımı içindeki melez yerli halka da kabul 
ettirmesi, adadaki bu melez halkın kendisini zamanla Yunanlı olarak görmesi sonucunu doğurmuştur.

1830'da Osmanlı İmparatorluğu'ndan bağımsızlığını kazanan Yunanistan, Osmanlı İmparatorluğu'na karşı besleyip büyüttüğü ve bir türlü kurtulamadığı tarihi-psikolojik saplantılarında köklerini bulan yayılmacılık ideolojisini 'Megali İdea Stratejisi' adı altında şekillendirmiştir. Nitekim Yunanistan'ın Osmanlı İmparatorluğu aleyhine yayılma stratejisi, Kurtuluş Savaşı'ndan ve daha sonrasında İkinci Dünya Savaşı ertesinde Türkiye'yi kuşatma stratejisi olarak gelişmiştir. Bu nedenledir ki, On İki Ada, Girit ve Rodos bin bir entrika ile Yunan egemenliğine sokulmuş ve Türkiye bir yay gibi Ege Denizi'nden kuşatılmıştır (Özmen 2007: 12.).

Kuşatmanın Akdeniz'den tamamlanması için, Yunanistan tarafından milli hedef olarak kabul edilen Megali İdea'ya göre (sözde) kadim bir Elen toprağı (!) kabul edilen Kıbrıs'ın da Yunan egemenliğine girmesi ve yayın güneyinin de tamamlanması gerekmektedir. Kıbrıs'ta Yunan sorununun temel nedeni budur. Rigas Ferreros adlı milliyetçi bir Yunanlı şair tarafından 1791'de Bükreş'te hazırlanan ilk Megali İdea haritası, 1796 yılında Viyana'da basılmış ve daha sonra Yunan yayılmacılığının temel belgesi haline gelmiştir. Megali İdea haritası içinde yer alan bölgelerin Yunanistan'a katılması, daha sonraları kurulan ve Yunanistan'ın bağımsızlığı ile Doğu Roma'nın yeniden ihyasını amaçlayan Etniki Eterya (Etniki Hetairia) gibi bütün ihtilalcı ve gizli Yunan yeraltı örgütlerinin hedefi olmuştur. Nitekim Etniki Eterya'nın faaliyet programındaki maddelerden birisi Kıbrıs'ın Yunanistan'a ilhakıdır (Türsan 1987: 40.). Unutulmamalıdır ki, Yunanlı ve Rum, 1798'de dağılan Etniki Eterya gizli yer altı örgütünün bu hedefinden 200 yılı aşkın bir süredir hiç vazgeçmemiştir. İşte, 200 yılı aşkın bir süredir Türkiye'nin aleyhine olmak üzere Megali İdea ve 50 yıldır da Enosis (İlhak) ${ }^{4}$ peşinde koşan Yunanistan için Kıbrıs budur, Kıbrıs'ın önemi budur.

Türkiye içinse, Kıbrıs'ın önemi çok daha fazla olması gerekirken, ülkemiz, 1923 yılından sonra aşırı bir iyimserlikle tarihsel "Megali İdea"nın Anadolu topraklarına gömüldüğünü düşünerek Yunanistan'la ilişkilerini sürekli bir dostluk temeline oturtmaya çalışmıştır (Sander 2007: 92.). Ancak Megali İdea kapsamında 1950'li yıllarda Kıbrıs'ta Türklere yapılan saldırıların artması üzerine, Türkiye 23 Ağustos 1955 tarihinde, "saldırıların devamı halinde sessiz kalınamayacağı" notasını vermiştir.

Zamanın Türkiye Dışişleri Bakanı Fatin Rüştü Zorlu, o dönemde yapmış olduğu bir konuşmada, Kıbrıs Adası'nın Yunanistan'a ilhak edilme düşüncesine karşı, şu tezi ileri sürmüştür; "Kıbrıs, coğrafi olarak Anadolu yarımadasının bir uzantısıdır. Bu yüzden ada Türkiye'ye ya da Türkiye çevresindeki doğulu ülkelerin kaderiyle en az Türkiye kadar yakından

\footnotetext{
${ }^{4}$ Adanın Yunanistan'a katılması.
} 
ilgili olan bir devlete ait olmalıdır. Savaş durumunda Türkiye'nin ikmali ancak batı ve güney limanlarından mümkün olabilecektir. Ama bu limanların hepsi Kıbrıs'ın gölgesi altındadır. Eğer bu adayı elinde bulunduran, aynı zamanda Türkiye'nin batısındaki adaları da elinde bulunduran bir devlet ise, o zaman Türkiye'yi etkinlikle çevrelemiş olacaktır. Hiçbir devlet kendi güvenliğini ne kadar yakın bir dost ve müttefiki olursa olsun, bir başka devlete bütünüyle teslim etmeyi göze alamaz." demiștir (Akt. Özmen 2007: 16.). 1955 yılında bir Türk devlet adamı tarafından deklare edilen bu ifadeler, Türkiye'nin Kıbrıs'a bakış açısını özetleyen çok net siyasi bir beyanattır. Dolayısıyla Kıbrıs, Türkiye için son derece kritik ve mutlaka elde bulundurulması ve/veya kontrol edilmesi gereken bir toprak parçasıdır.

Doğu Akdeniz'de Türkiye'nin güneyden göğsüne yönelmiş bir hançer konumuyla Kıbrıs, Türkiye'nin milli güvenlik siyaseti için vazgeçilmez stratejik değer taşımaktadır (TESSAM 2008: 3.). Hatta bu konumuyla Kıbrıs, hiç şüphesiz ki ulusal ve uluslararası güvenlik boyutunda Türkiye için hayati önemi haiz bir coğrafya parçasıdır. Bu bağlamda, Kıbrıs Adası'nın, Doğu Akdeniz'de merkezi konumu nedeniyle her zaman stratejik önemini korumaya devam edeceği yadsınamaz bir gerçektir. Zira Kıbrıs'ın, Türkiye'nin yakın kara havzası olarak kabul edilen Balkanlar, Kafkaslar ve Orta Doğu bölgeleri ile Anadolu'nun güney sahillerine olan yakınlığı, Ege Denizi'nden Akdeniz'e geçişleri kontrol etme olanağına sahip olması, Orta Doğu, Mısır ve Süveyş Kanalı'na yakın bulunması onu geniș alanlar üzerinde hâkim bir konuma getirmektedir.

Dolayısıyla Kıbrıs'ın, Türkiye açısından Doğu Akdeniz'deki hassas coğrafi konumunu 'ulusal güvenlik' ve 'stratejik konum' gibi kavramlarla tanımlamak hiç de yanlış olmayacaktır. Nitekim "ulusal güvenlik"; bir devletin anayasal düzeninin, milli varlığının, bütünlüğünün, uluslararası siyasi, sosyal, kültürel, ve ekonomik bütün menfaatleri ile ahdi hukukunun; çevre kirliliği, nüfus artışı, bölgeler arası göç, gelir dağılımı, açlık, işsizlik vb. dahil, her türlü tehdide karşı korunması ve kollanmasıdır (Çörekçi 2001: 44.). Stratejik konum ise, bir toprak parçasının stratejik değeri, kaybedildiği takdirde, düşmanın olanak ve yeteneklerini ne ölçüde artıracă̆ı ile ölçülür. Düşman, ele geçirdiği bu stratejik mevkiden bir dizi harekete girişebilir. Söz konusu stratejik mevkii kaybeden dost kuvvetlerin savunma gücü, hasmın bu mevkiden yapacağı girişimler karşısında önemli ölçüde azalır (Art ve Waltz 1971: 6.).

Adanın Türkiye açısından her zaman büyük olan stratejik önemi, özellikle son yıllarda uluslararası alanda ve bölgede meydana gelen hızlı siyasi ve ekonomik gelişme ve değişimler nedeniyle daha da artmaktadır. Bakü-Tiflis-Ceyhan (BTC), Kerkük-Yumurtalık ve gelecekteki Samsun-Ceyhan boru hatları gibi Türkiye'nin deniz yetki alanlarını geçmişe nazaran çok daha önemli kılan enerji projelerinin hayata geçmesi, Türkiye-İsrail ilişkilerinin bozulması, GKRY'nin Doğu Akdeniz deniz yetki alanlarında İsrail'i de yanına alarak tek taraflı girişimlerle sözde münhasır ekonomik bölgesinde hidrokarbon zenginliklerini arama faaliyetleri gibi uluslararası 
hukuka aykırı eylemlere kalkışması, Türkiye'nin Kıbrıs özelinde Doğu Akdeniz'e bambaşka bir dikkat, önem ve özen göstermesini gerekli kılmıştır. Ayrıca, Türkiye'nin Doğu Akdeniz'de Kıbrıs'a ilişkin eski ve yeni deniz ve hava sahası problemlerinin, Yunanistan'la Ege'de yaşanan sorunlarla da direkt ilintili olması, günümüz Kıbrıs'ını Türkiye için daha hayati bir statüye sokmuştur.

$\mathrm{Bu}$ hayati konumunun paralelinde, Kıbrıs'ın önemi sadece Türkiye'ye yakınlığından ileri gelmemektedir. Zira eski çağlardan beri Doğu Akdeniz'deki deniz ticaret yolları ile deniz ulaştırmasını ve enerji nakil hatlarını kontrol altında bulunduran Kıbrıs'ın, Doğu Akdeniz'in ortasında batmaz bir uçak gemisi olarak, çok değerli bir mavi vatana sahip olmasından kaynaklanan jeostratejik, jeopolitik ve jeoekonomik önemi ve değeri bulunmaktadır. Zaten günümüzde İngiltere'nin Kıbrıs'ta tam hükümran ülke haklarıyla sahip olduğu topraklar ve buralardaki askeri üsler dikkate alındığında, İngiltere'nin 1945-1947 yılları arasında Dışişleri Bakanlığı'nı yapmış Anthony Eden (1897-1977)'in; “Kıbrıs olmazsa, petrolün Íngiltere'ye taşınmasını koruyacak tesisler de olmayacaktır. Petrolün olması demek, Ingiltere'de işsizlik ve açlık demektir. Bu kadar basit!" sözleri, Kıbrıs'ın İngiltere açısından sahip olduğu jeostratejik önemi ortaya koymaya yetmektedir (Akt. Kantarcı 2004: 37.). Bu bağlamda;

- Kıbrıs Adası, Anadolu'nun en önemli ihracat ve ithalat limanları olan ve NATO'nun Orta Doğu'daki bir harekâtında silah, malzeme ve personel transferi maksadıyla kullanılmak üzere 'hub-port (toplanma limanı)' olarak benimsediği Mersin ve İskenderun'a giriş ve çlkışı kontrol etmektedir.

- Doğu Akdeniz'deki, hatta Türk Boğazları'nın ve Süveyş Kanalı'nın açıldığı Akdeniz'deki bütün deniz ticaretini, deniz ulaştırmasını kontrol edebilecek olanaktadır.

- Kafkas, Hazar havzası ve Kerkük-Musul petrollerinin ve doğal gaz boru hatlarının ulaştığı İskenderun Körfezi'ni koruma ve kontrol bakımından eşsiz bir stratejik konuma sahiptir.

- Kıbrıs'ta konuşlandırılacak askeri güçler, özellikle deniz ve hava kuvvetleri ile orta/uzun menzilli füzeler, adanın merkezi konumu nedeniyle, Anadolu ve güney sahillerimiz dâhil bölge ülkelerini etkileri altına alabileceklerdir.

- Türkiye, yeni gelişmekte olan Asya ekonomik pazarının batı kapısı üzerindedir. Asya, dünya ile deniz bağlantısını Batı'da, Türkiye'nin Akdeniz kapısı üzerinden sağlayacaktır. Dolayısıyla bu batı kapısının kilidi Kıbrıs'tır.

- Kıbrıs, Türkiye'nin güney sahillerinin emniyetini ve denizden/havadan güvenliğini sağlamakta ve bu bölgedeki kuvvetler için ileri bir harekât üssü, ikmal üssü vazifesi görmektedir.

- Kıbrıs, bir mütecaviz devletin elinde bulunması durumunda, Türkiye'yi güneyden tehdit ederek, güney bölgesinde büyük çaplı bir askeri kuvvet bulundurulmasını zorunlu kılacaktır. 
- Kıbrıs, Ege'de Yunanistan'a verilmiş adalarla batıdan kuşatılmış durumda bulunan Türkiye'ye güneyden Akdeniz'e emniyetli çıkış imkânı sağlamakta, bölgeye yönelik deniz ulaştırma hatlarını kontrol altında bulundurmakta ve Türkiye'nin stratejik savunma derinliği açısından hayati önemi bulunmaktadır.

- Kıbrıs'ın Türkiye'nin etkin olmadığı bir siyasi birliğin kontrolüne girmesi durumunda, günümüzde Ege'de Yunanistan'la yaşanan kara suları, kıta sahanlığı, hava sahası, gibi sorunların benzerleriyle Kıbrıs ve civarındaki deniz ve hava sahalarında da karşılaşılacaktır.

- Bütün Orta Doğu'yu, petrol bölgeleri ve özellikle Türkiye açısından Anadolu'yu menzili içine alabilecek kapasitede olan füzelere rampa, uçaklara hava alanı hizmeti verebilecek 'batmayan bir uçak gemisi' niteliğindedir.

- Son zamanlarda Yunanistan ile GKRY arasında ortak savunma doktrini çerçevesinde sürdürülen askeri faaliyetler, Yunanistan-GKRY-İsrail arasında siyasi, askeri ve ekonomik yakınlaşma ve işbirliği faaliyetleri ve GKRY'nin AB'ye tam üyeliği ile Ocak-Temmuz 2012 arasında AB Dönem Başkanlığı dahi icra ettiği dikkate alındığında Kıbrıs'ın öneminin daha da arttığı görülmektedir.

- Kıbrıs'ta yaklaşık 200.000 egemen Türk nüfus yaşamaktadır. Türkiye Cumhuriyeti'nin, bu Türk nüfusun yaşama hakkını, temel hak ve özgürlüklerini korumak gibi milli, tarihi, hukuki ve insani bir görevi bulunmaktadır. Sadece bu görevi yerine getirebilmesi için dahi Türkiye'nin Kıbrıs'ın mukadderatı ile ilgilenmesi kaçınılmaz bir sorumluluk ve görevdir.

\section{TÜRKIYE'NIN DOĞU AKDENİ'DE DENİZ GÜVENLİĞİNE KATKILARI}

Kıbrıs'ın Türkiye için jeostratejik, jeopolitik ve jeoekonomik öneminin sadece geçmişin şartları içerisinde değil, günümüzde bölgesel bir güç olarak yükselen Türkiye'nin, hızla değişen dünya düzeninde, bölgesinde, özellikle de Doğu Akdeniz'de deniz güvenliği kapsamında barış ve istikrara sağladığı katkıları da değerlendirmek gerekir.

Zira denizalanı, yeni dünya düzeninde ortaya çıkan yeni tip risklerin istismarına ve bu risklerin tehditlere dönüşmesine imkân sağlayan ideal bir ortam sunmaktadır. Bugünün dünyasında, bütün deniz devletleri deniz alanlarının emniyeti ve deniz güvenliği konusunda artan bir kaygı taşımaktadırlar. Yeni küresel güvenlik ortamının Türkiye'yi çevreleyen denizler üzerinde de yansımaları olmuştur. Türk Deniz Kuvvetleri, yeni güvenlik ortamına uygun olarak, Sahil Güvenlik Komutanlığı ve ilgili diğer kurumlar ile yakın işbirliği halinde, çok yönlü, dinamik ve derinliğine savunma anlayışına sahip, güvenlik üreten bir kuvvet hâline dönüşmüştür. Bu durum, deniz kuvvetlerimize konvansiyonel görevlerinin yanı sıra kolluk görevlerini de içeren yeni sorumluluklar yüklemiştir. Türkiye'nin Akdeniz, Karadeniz ve Ege denizindeki ilân edilmiş ve ilân edilmemiş deniz yetki alanları Türkiye yüzölçümünün yaklaşık yarısına eșit büyüklükte bir alanı kaplamaktadır. Gelecek nesillerin Türkiye'nin deniz yetki alanlarındaki deniz dibi 
kaynaklarına ve zenginliklerine yönelik bağımlılığı bu konuya hukukî ve çevresel açıdan özel dikkat ve ilgi göstermemizi dikte etmektedir.

Doğu Akdeniz'de, Bakü-Tiflis-Ceyhan (BTC) ve Kerkük-Yumurtalık boru hatlarının uzandığı İskenderun körfezinin özel bir bölge olarak ortaya çıkmakta olduğu görülmektedir. Her iki boru hattı da tam kapasiteye ulaştığında bu bölgeden yılda 140 milyon ton petrol küresel pazara aktarılacaktır. Böylece, İskenderun körfezinden başlayan deniz ulaştırma hatları aynı zamanda dünyanın enerji ağlarını besleyen yeni hayat damarları hâline gelecektir. SamsunCeyhan hattı da tamamlandığında bölgenin kapasitesi 190 milyon tona ulaşacaktır.

Bu hayatî bölgede ve deniz ulaştırma hatları boyunca küresel ve bölgesel enerji güvenliğini destekleyecek şekilde derinliğine deniz güvenliğinin sağlanması Türk Deniz Kuvvetleri açısından çok önemli bir görev hâline gelmiştir. Bu kapsamda, Türk Deniz Kuvvetleri terörizmin, Kitle İmha Silahları yayılmasının ve diğer yasa dışı faaliyetlerin önlenmesi maksadıyla, Doğu Akdeniz'de, Birleşmiş Milletler Güvenlik Konseyinin ilgili kararlarının sağladığı hukukî çerçeve temelinde 1 Nisan 2006 tarihinde "Akdeniz Kalkanı Harekâtı (Operation Mediterranean Shield)" adı altında bir deniz güvenlik harekâtını başlatmıştır. Bu harekâtın amacı İskenderun'dan çıkan petrol ulaştırma hatlarının batı ve güney eksenlerinde sancak ve varlık göstererek caydırıcılık sağlamak ve denizde durumsal farkındalığı tesis etmektir. Bu harekât esnasında deniz trafiğine yönelik elde edilen bilgiler, NATO’nun ilgili karargâhları, Aktif Çaba Harekâtı (Operation Active Endeavour)'na katılan unsurlar, UNIFIL unsurları ve İtalyan deniz kuvvetlerinin öncülük ettiği sanal bölgesel trafik merkezi gibi hâlihazırda Akdeniz'de faaliyet gösteren bölgesel ve milli girişimlerle paylaşılmaktadır.

Türk Deniz Kuvvetleri Aktif Çaba Harekâtı'na, başlangıç tarihi olan Ekim 2001'den itibaren destek vermektedir. Türkiye, bugüne kadar yaklaşı 250.000'den fazla geminin sorgulandığı ve 200'ün üzerinde rızaya dayalı (invited-boarding) gemiye çıkmanın icra edildiği bu önemli deniz güvenlik harekâtına azami sayıda gemiyle katılım sağlamıştır. Akdeniz Kalkanı Harekâtı ve Aktif Çaba Harekâtı, birbirini tamamlayan ve Doğu Akdeniz'de eş güdüm ve işbirliği içerisinde kesintisiz sancak/varlık gösterilmesini sağlayan harekâtlardır. Buna ilave olarak, Birleşmiş Milletler tarafından Lübnan'ın deniz sahalarının denetlenmesi maksadıyla icra edilen UNIFIL deniz harekâtı da bölgede sancak/varlık göstermek suretiyle aktif olarak deniz güvenliğine katkıda bulunmaktadır. Türk Deniz Kuvvetleri UNIFIL deniz harekâtına başlangıcından itibaren firkateyn, korvet, hücumbot ve destek gemileri ile katkı sağlamaktadır.

Türkiye, çevre denizlerinden özellikle Doğu Akdeniz'de güvenliği sağlayarak, bölgesel olduğu kadar küresel barış ve istikrara ve aynı zamanda enerji güvenliğine de katkıda bulunmaktadır. Deniz ortamında gerçekleştirilecek girişimlerle sahildar ülkeler arasında yakınlaşmanın artırılabileceğine ve bunun sağlayacağı etkileşimlerle çevremizde daha güvenli ve 
emniyetli denizler yaratılabileceğine inanılmaktadır. Önemli olan sahildarlar arasında gereken yer ve zamanda bilgi değişimine ve koordineli denizde denetim harekâtına yönelik bir sinerji oluşturmayı başarmaktır. Her şeyin ötesinde deniz güvenliğinin birbirine bağlı ve ayrılmaz bir bütün olduğu gerçeği kabul edilmelidir. Dünyada hiçbir ülke, ister bölgesel, ister küresel çapta olsun, denizde meydana gelen bir olayın, emniyet, güvenlik, çevre, enerji, ticaret, turizm veya yerel istikrara yönelik menfi etkilerine karşı bă̆ışık değildir (Gürdeniz 2007: 277-279.).

Görüldüğü üzere, Türkiye'nin deniz güvenliğine bir takım milli ve uluslararası deniz harekâtlarıyla önemli katkılarda bulunduğu Doğu Akdeniz ve onun da özelinde Kıbrıs Adası, Türkiye'nin ulusal güvenliğini çok yönlü olarak ve doğrudan tehdit edebilecek bir özelliğe sahip olduğu gibi, onun ulusal güvenliğini büyük ölçüde tamamlayan değerlere de sahiptir (Öztürk 2004: 52.).

\section{DOĞU AKDENIZ'DE DENIZ YETKI ALANLARINA İLIŞKINN SON GELIŞMELER}

Şimdi, Kıbrıs'ın etrafında son yıllarda daha da alevlenen uluslararası politik bir konu olan "Doğu Akdeniz'de deniz yetki alanlarının sınırlandırılması" sorununa değinilecektir. Zira bu sorun, Kıbrıs'ı çevreleyen suları hayli ısıtmıştır. Bugün Doğu Akdeniz'de yaşanan bu sondaj krizi vb. sorunların temelinde, Güney Kıbrıs Rum Yönetimi ve Yunanistan'ın Doğu Akdeniz'deki denizlerin hepsini, uluslararası hukuka aykırı olarak sahiplenmek istemeleri yatmaktadır. Uluslararası ilişkilere ve politikaya göre bu sahiplenme şu anlama gelmektedir: Bugün Doğu Akdeniz'de boyutları giderek büyüyen bir deniz yetki alanları uyuşmazlığı ortaya çıkmıştır ve bölgede olduğu söz edilen hidrokarbon yatakları bu uyuşmazlığı alevlendirmektedir.

$\mathrm{Bu}$ denizin tabanının altında, bilimsel olarak da kanıtlanmış biçimde, çok yüksek değerde hidrokarbon zenginlikleri mevcuttur. (Piyasa değeri takribi 7 trilyon dolar olan 15 Trilyon metreküp doğalgaz ve petrol). Bu deniz altı zenginliğini Rumlar 1990’lı yıllarda öğrenmiş; 2000 yılından itibarense konu, Kıbrıs Rum basınında geniş şekilde yer almıştır. Doğu Akdeniz'de zengin hidrokarbon yataklarının varlığıyla ilgili bulguların artmasıyla birlikte maalesef önce GKRY inisiyatifiyle bölgede deniz yetki alanlarının sınırlandırma faaliyetleri hız kazanmıştır. Bu kapsamda, GKRY, deniz yetki alanlarının sınırlandırılmasında atak, akılcı ve sinsi davranarak, üç ülke ile MEB sınırlandırma anlaşması imza etmiştir. Rum yönetimi izlediği politikalar kapsamında, Şubat 2003'de Mısır ile, Ocak 2007'de Lübnan ile MEB anlaşmaları imzalamıștır. Türkiye'ce Lübnan'a yapılan baskılarla parlamentosunun GKRY anlaşmasını onaylaması engellenmiştir. Ancak, GKRY son olarak 17 Aralık 2010 tarihinde İsrail ile Lefkoşe'de MEB sınırlandırma anlaşması imzalamıştır. Nitekim ABD kaynaklı bir petrol arama şirketinin 19601974 yılları arasında Geçitkale Havaalanı’nın güneyinde bir kuyusunun, Gazi Mağusa doğusundaki açık denizde de bir petrol kulesinin bulunduğu biliniyor. 1974 Barış Harekâtı 
sırasında karadaki kuyu beton ile kapatılmış. Denizdeki kule ise sökülerek götürülmüş. Diğer deyişle, adada petrolün var olduğu uzun yıllar önce biliniyordu (Keser 2007).

Türkiye, Doğu Akdeniz'de münhasır ekonomik bölge (MEB) ilan etmemiștir. Ancak, Türkiye ile KKTC, bu teşebbüslere başından itibaren karşı çıkmış; bölgede sınırlandırmanın ilgili devletler arasında hakkaniyete uygun olarak yapılması gerektiğini, GKRY'nin tek başına Kıbrıs adasını temsil etmediğini, KKTC'nin yok sayılarak yapılan anlaşmaların geçersiz olduğunu ve bunları tanımayacaklarını beyan etmektedirler. Bu kapsamda Türkiye, 2 Mart 2004 tarihinde Mısır-GKRY Anlaşmasını tanımadığını uluslararası topluma beyan ederek, BM nezdinde protesto etmiştir. Bu konudaki ilgili nota, BM Nezdinde Türkiye’nin Daimi Temsilciliğinin 2 Mart 2004 tarihli, 2004/Turkuno DT/4739 sayılı Notası'dır. BM’ye gönderilen metinde, 32우 16’ 18” Doğu boylamının batısında kalan deniz sahasında Türkiye'nin hakları olduğu ifadesi de yer almıştır. Türkiye, Doğu Akdeniz'de henüz bir MEB ilan etmemiş olmakla birlikte, muhtemel Türk MEB sınırları içerisinde yaptığı çeşitli devlet uygulamaları ile GKRY'nin bu hukuk dışı girişimlerini kabul etmediğini göstermektedir. Diğer deyişle, GKRY'nin tek başına bu antlaşmaları yapmaya yetkisi bulunmamaktadır. Adada GKRY tarafından temsil edilmeyen bir başka halk, Kıbrıs Türk halkı ve onun devleti olan Kuzey Kıbrıs Türk Cumhuriyeti vardır. Bu bağlamda bu meselenin, Kıbrıs uyuşmazlığının denize yayılması olduğunu söylemek hiç de yanlış olmayacaktır.

Rum Kesimi'nin önemli bir amacı, Kıbrıs sorunu karadan denize de taşıyarak, fiili durum yaratmaktır. Bugüne kadar Doğu Akdeniz'deki kaynakların Kıbrıs sorunu çözülmeden kullanılmaması yönünde bir teamül gelişmişti. Türk tarafı da Kıbrıs sorunu hallolunduktan sonra bu kaynakların Ada'nın her iki kesimince hakkaniyete uygun olarak kullanılması yönünde tavır ortaya koymuștu. Zira bugünkü durumda Rum Kesimi'nin elde edeceği ekonomik zenginlik Türk tarafına hiçbir fayda sağlamayacak, bu durum da Adadaki Türklerin haklarının gasp edilmesi anlamına gelecektir. Üstelik çıkarılan kaynakların nasıl paylaşılacağı konusunda da derin muammalar vardır çünkü ortaya devlet yapılanmasına ve temsiliyete ilişkin bir sorun bulunuyor. Rum Kesimi'nin son hamlesi kendi içinde yeterince karmaşık olan Kıbrıs sorununu denize de taşıyarak süreci iyice içinden çıkılmaz hale getirmiştir.

AB başta olmak üzere uluslararası kuruluşların ve ABD gibi etkin küresel aktörlerin bilincinde olması gereken de bu durumdur. Diğer deyişle, Kıbrıs sorunu karadan denize taşınırsa çözümü çok daha zor olabilir ve güç kullanımı riski açı biçimde artar. Rum Kesimi, son adımıyla bilinçli bir şekilde kriz tırmandırma stratejisi izlemiş, İsrail-Türkiye ilişkilerinin gerilmesini de mükemmel bir firsat penceresi olarak değerlendirmiștir. Diğer taraftan belirtmek gerekir ki Rumların bu kadar hızlı bir şekilde bu işe girişebilmelerinin arkasında İsrail'in politik ve lojistik desteği bulunmaktadır. Zira İsrail'in politik taahhütleri olmadan bir enerji şirketinin bu kadar netameli bir alana yatırım yapmasını beklemek mümkün değildir. Ayrıca gereken siyasi ve 
lojistik destek olmadan Rum Kesimi'nin de bu girişimde bulunmasını beklememek gerekir (Kutlay 2012: 22.).

Bu çerçevede GKRY, özellikle Mısır ve Lübnan ile iki MEB sınırını kendince çizdikten sonra, 26 Ocak 2007 tarihinde ise Kıbrıs adasının güneyinde, toplamı $51.000 \mathrm{~km} 2$ olan 13 adet petrol arama ruhsat sahası ilan etmiştir. Nitekim bu alanda, 2006 ve 2009 yılları arasında PGS Geophysical AS tarafından 2D ve 3D sismik operasyon yapılmıştır. 15 Şubat 2007 tarihinde, 2006 yılı sismik verilerine bağlı olarak, bu sahaların 11'inde bütün yabancı petrol şirketlerini davet ederek uluslararası ihale açmıştır. Rumların, Mısır'a doğru olan Kıbrıs güneyi deniz bölgesinde parselleyip ruhsat verdiği 13 sahadan beşi Türkiye'nin muhtemel kıta sahanlığı ile çakışmış ve bu çakışan bölgeye giren araştırma gemisi Türk savaş gemilerinin uyarısı ile bölgeden uzaklaştırılmıştır. Türkiye, Rumlarca bu yapılan tek taraflı ve uluslararası komşuluk, hakkaniyet ve nısfet kurallarına aykırı parselli sahalarda 2007 yılı içinde deniz ve hava kuvvetleri unsurlarıyla atışlı tatbikatlar yapmıştır. Rumlar, sahaların siyasi ve hukuki açıdan problemsiz olma özelliğini koruyabilmek ve yabancı petrol şirketleri kaçıp korkmasın diye bu faaliyetleri sessizlikle izlemişler, basınlarına gizli sansür uygulamışlar, medyasında haberlerin yayınına minimize yapmışlardır.

Teklif verme süreci Ağustos 2007'de tamamlanan, Rumların açtığı uluslararası petrol/doğalgaz arama ihalesinde, günümüzde Afrodit ismiyle bilinen 12 nolu saha için ABD şirketi Noble Energy teklif vermiş ve ihale süreci tamamlanarak, ABD firması 18 Eylül 2011'de 12 nolu parselde, şirkete ait Homer Ferrinton petrol platformu marifetiyle hidrokarbon sondaj faaliyetlerine başlamıştır. Rum basın haberlerine göre, sondaj çalışmalarının başladığı nokta Limasol'a 160 kilometre (80 deniz mili) mesafededir ve platforma helikopterle 45 dakikada ulaşılabilmektedir. Söz konusu bölgede su derinliği 1650 metredir ve sondajın ulaşacağı toplam derinlik 5.800 m. olacaktır.

Son yıllarda gittikçe tırmanan bu tek taraflı Rum uygulamaları karşısında, Türkiye'nin "bekle-gör” gibi bir dış politika uygulama lüksü bulunmamaktadır. Zira bir Yunanlı gazetecinin Kıbrıs'la ilgili bir yazısında da vurguladığı gibi; “Uluslararası politikada önemli olan söylenenler değil, yapılanlardır." Bu nedenle, yaşanan son gelişmeler paralelinde daha aktif bir yol izlemeye karar veren ve bu paralelde icraata geçen Türkiye ile KKTC, New York'ta 21 Eylül 2011'de Kita Sahanlığı Sınırlandırma Anlaşması imzalamıștır. Hemen hitamında, 22 Eylül 2011'de KKTC Bakanlar Kurulu TPAO'ya Ada çevresinde petrol arama ruhsatı vermiştir. KKTC tarafından TPAO'ya verilen arama izninin süresiz olduğu, aramalar sırasında petrol veya gaz bulunması halinde, kaynakları çıkarmak maksadıyla Türkiye ile yeni bir anlaşma imzalanacağı bildirilmiştir. Anılan ruhsata istinaden Türkiye'den talep edilen Piri Reis araștırma gemisi 23 Eylül 2011 günü KKTC'nin belirlediği yedi adet ruhsat sahasından birisi olan “G Bölgesi”nde sismik araştırma 
faaliyetlerine başlamıştır. Piri Reis'in bölgedeki faaliyetlerinden hedeflenen ulusal çıkarın şu şekilde olduğu değerlendirilmektedir; Rumlar, İsrail'le derin bir işbirliği halinde, Kıbrıs'ın güneyinde Kıbrıslı Türklerin de mevcut haklarını hiçe sayarak, adeta adanın tek siyasi otoritesiymiş gibi davranmaktadır. Dolayısıyla Türkiye, Güney Kıbrıs'ın tek başına bütün Kıbrıs adına anlaşma yapma yetkisi olmadığını belirterek, bölgede Güney Kıbrıs Rum Yönetimi'nin yaptığı kıta sahanlığı sınırlandırması anlaşmalarını tanımamaktadır.

Piri Reis'in bölgeye varması sonrası yaşanan siyasi gelişmeler ise şu şekildedir. KKTC Cumhurbaşkanı Dr. Derviş Eroğlu, BM Genel Sekreteri Ban Ki Moon ile 24 Eylül 2011'de gerçekleştirdiği görüşmede tüm çalışmaların eş zamanlı olarak kapsamlı çözüme kadar askıya alınması, BM aracılıyla kurulacak üçlü bir komiteyle hidrokarbon faaliyetleri için iki tarafın yazılı rızalarının alınması, elde edilecek gelirin kapsamlı çözümdeki finansman ihtiyacı için kullanılması durumunda, hiçbir biçimde silahlanma veya benzeri faaliyetler için kullanılmaması şeklinde öneriler sunmuştur. GKRY, 26 Eylül 2011'de yaptığı açıklamada söz konusu önerileri "kabul edilemez" bulduğunu beyan etmiştir; ancak daha öncesinde zamanın ABD Dışişleri Bakanı Hillary Clinton’un “Güney Kıbrıs'ın Akdeniz'de petrol ve doğal gaz aramaya hakkının olduğu" şeklindeki açıklaması ile GKRY tarafını destekler pozisyonda olan ABD, KKTC Cumhurbaşkanı Derviş Eroğlu'nun anılan önerileri sonrasında Dışişleri Bakanlığı Sözcüsü Victoria Nuland'ın “Biz daha önce de BM önderliğinde ve arabuluculuğunda barışçıl bir çözüm görmek istediğimizi birçok kez söyledik. Biz adanın kaynaklarının halklar arasında paylaşılmasını görmek istiyoruz. BM önderliğindeki gelir paylaşımı arabuluculuğu teklifini ilgiyle karşıllyoruz." şeklindeki açıklaması ile ilk kez Türk tarafının tezlerine yakın bir pozisyon almıştır.

Bununla birlikte, KKTC'nin aslında daha en baştan itibaren; MEB ilanları, ihale süreçleri, gelirlerin paylaşılması gibi temel konularda karar mekanizmalarında da yer almasının konunun özünü teşkil ettiği düşünülmektedir. Zira Kıbrıslı Türkler, Rumların 'astı' değil, en azından 'eşiti'dir. Bu arada, GKRY'nin Afrodit isimli 12 nolu parsele ilave olarak bölgedeki 4-5 parsel için de sondaj izni verme çalışmaları başlattığı, yeni sondaj izinlerini Rus Gazprom, Fransız Total ve Gaz De France, İngiliz Shell'e vermek istediği, yeni ihaleler için Amerikan Chevron ve Norveçli Statoil'in de ilgilendiği basın-yayın organlarında yer almıştır. Noble Energy şirketinin 28 Aralık 2011'de GKRY'nin sözde MEB'inde yürüttüğü doğal gaz sondaj çalışması ile ilgili yaptığı açıklamada; 12 nolu parselin doğal gaz rezervinin \% 25-75 ihtimal aralığında 5 ila 8 trilyon feet küp arasında olduğu, 12 nolu parselin yaklaşık 40 mil karelik bir alanı kapladığı ve son gelişmeler paralelinde ilave sondaja ihtiyaç duyulacağı belirtilmiştir. Nitekim söz konusu şirketin 15 Kasım 2011'de konuya ilişkin yaptığı basın açıklamasında; 12 nolu parselin doğal gaz rezervinin (başlangıçta 10 trilyon feet küp tahmin edilmiştir) 3 ila 9 trilyon feet küp arasında, 
jeolojik başarı oranının ise \% 60 civarında olduğu, doğal gaz rezervinin altında 3.7 milyar varil civarında petrol yatağının tespit edildiği belirtilmiştir.

Dönemin GKRY lideri Hristofyas'ın ise, son keşif ve gelişmeler kapsamında; anılan rezervin değerinin 60 milyar Amerikan Doları olduğu, bölgede sondaj faaliyetlerinin devam edeceğini ve Türkiye'nin uluslararası hukuka saygılı olması gerektiği, Kıbrıs sorununda anlaşmaya varılması halinde, doğalgazdan Kıbrıslı Türklerin de yararlanacağının beyan ettiği basında yer almıştır. Bu süreçte, 23 Kasım 2011'de Türkiye ile Shell şirketi arasında önümüzdeki dönemde Akdeniz açılarında (Antalya, Mersin, İskenderun körfezleri) Türkiye’nin kıta sahanlığı içerisinde petrol ve doğalgaz araması yapılması konusunda bir anlaşma imzalanmıştır.

Ancak, günümüze kadar bölgede hidrokarbon kaynaklarının aranması konusunda ortaya iki önemli gerçek çıkmıştır. Rumların adanın güneyinde verdiği ruhsatlara binaen 5000 metre derinliğe kadar sondaj ve arama çalışmaları yapan uluslararası şirketler, Rumların denizden parsellediği, ruhsatlandırdığı ve çok değerli hidrokarbon kaynaklarının varlığından ve çlkarılmasından bahsettiği ortamda, hiçbir bulgu elde edememişlerdir. Zira jeoloji mühendisliği ve bilimi açısından da çeşitli toplantılarda dile getirildiği şekilde, adanın güneyinde deniz tabanı altında petrol,doğal gaz gibi hidrokarbon kaynaklarının oluşması bilimsel olarak mümkün değildir. Zaten yaşananlar da bilimi destekler şekilde tezahür etmiştir. Öte yandan Türkiye de, son 10 yılda Doğu Akdeniz'de kendi -ancak henüz ilan etmediği- deniz yetki alanlarına ilişkin siyasalarını, çalışmalarını başarıyla ve de uluslararası hukuka ve uluslararası ilişkilerde hakkaniyete uygun olarak sürdürmüş ve hala da sürdürmektedir.

\section{SONUÇ VE ÖNERILER}

Bu çalışmanın başlıca bulguları, Doğu Akdeniz'de Türkiye'nin KKTC ile birlikte çeşitli jeostratejik ve jeoekonomik çıkarlarının mevcudiyetini ve bunların ulusal güvenlik mülahazaları çerçevesinde vazgeçilemez olduğunu ortaya koymaktadır. Bu bağlamda ilk olarak, Armaoğlu (1983: 5.)'nun konuyla ilgili; “Kıbrıs, Yunanistan için, her zaman emperyalist ve yayılmacı politikasının bir hedefi; Türkiye için, tarih boyunca bir ulusal güvenlik ve savunma meselesi olmuştur." şeklindeki veciz tespitini göz önünde tutarak, unutulmamalıdır ki, stratejide yapılan hatayı taktikle düzeltmek mümkün değildir. Daha önemlisi, GKRY'nin tek başına adayı temsil etme hakkı bulunmamaktadır; ancak GKRY'nin tek başına adanın kaynaklarını kullanmasına izin verilir ve GKRY, bölgede varlığı kanıtlanan hidrokarbon kaynaklarına tek başına tasarruf ederse, Kıbrıs görüşmelerinde taleplerini arttıracak uzlaşmaz bir tutum benimsemesi kaçınılmaz olacaktır. Keza Hristofyas'ın seçilmesinden sonra görüşmeler için diplomatik hareketlilik sürerken, her ne kadar 'sanal petrol krizi' ötelenmiş gibi görünse de, bu koz Rum yönetiminin elinde her an harekete geçirilebilecek şekilde hazır tutulmaktadır. 
Ayrıca, son yıllarda gözlemlendiği üzere Rumlar, İsrail'le derin bir işbirliği halinde, Kıbrıs'ın güneyinde Kıbrıslı Türklerin de mevcut haklarını hiçe sayarak, adeta adanın tek siyasi otoritesiymiş gibi davranmaktadır. Dolayısıyla Türkiye, Güney Kıbrıs'ın tek başına bütün Kıbrıs adına anlaşma yapma yetkisi olmadığını belirterek, bölgede Güney Kıbrıs Rum Yönetimi'nin yaptığı kıta sahanlığı sınırlandırması anlaşmalarını tanımamaktadır. Yine de, Bryza (2013: 38.)'nın “İsrail'in, elindeki diğer hatlara ilave olarak, siyasi ve ticari sebeplerle Türkiye'ye uzanacak bir LNG terminali ile boru hattını tercih etmesinin büyük olasılık" olduğunu vurgulaması, bölgedeki her türlü ilişki ve dengenin hala ne kadar oynak olduğunu göstermektedir.

Bölgede yaşanan son gelişmeler göstermektedir ki, Doğu Akdeniz'de statükoyu bozucu bu tek taraflı girişim ve faaliyetleri, Kıbrıs Sorunu'nu deniz alanlarına da taşımıştır. Her ne kadar Rumlar, bulunan hidrokarbon zenginliklerinden Kıbrıslı Türklerin de yararlanacağını belirtse de, yıllardır her ne hikmetse adayı birleştirmeye uğraşan zihniyetlerin Rumların bu zenginliği Kıbrıs Türklerine kesinlikle pay etmeyeceğini, bu zenginliğin Rumların iştahını kabartarak, adada gerçek bir bölünmeye kadar gidecek bir sürecin başlangıcı olduğuna inanılmaktadır.

Tarihin her döneminde Kıbrıs, Anadolu'da kurulan Türk devletlerinin ulusal güvenliklerinin sağlanmasında hayati rol oynamıștır. Bugün de Türkiye'nin 'hayat alanı' olarak kabul edilen Doğu Akdeniz'in merkezinde yer alan Kıbrıs, Türk ulusunun güvenliği için hayati önemi olan bir adadır. Anamur'dan sadece $65 \mathrm{~km}$. uzakta bulunan ve sahile yakın yüksek bir yerden bakıldığında çıplak gözle görülebilen Kıbrıs, etle tırnak misali Türkiye'nin ve onun ulusal güvenliğinin ayrılmaz bir parçası olarak değerlendirilmektedir. Bundan dolayı Türkiye, Kıbrıs'ta meydana gelen gelişmelere ve siyasi yapısında oluşturulmak istenen değişikliklere karşı kayıtsız kalamaz. Zira Türkiye'nin hayat alanı olarak kabul edilen Kıbrıs'a dost veya düşman bir gücün doğrudan ya da dolaylı olarak yerleşmesi, onun ulusal güvenliğini yakından, ciddi ölçüde olumsuz olarak etkileyecektir. Maruz nedenlerle Kıbrıs, Türk Milleti'nin gönlünde ve vicdanında her zaman milli bir dava olarak kabul edilmeli ve Türkiye Cumhuriyeti'nin milli hedeflerinin başında yer almalıdır.

Hiç şüphe yok ki, devletler dış politikalarında duygusal veya ideolojik eğilimlere göre değil, ülkeye sağlayacağı yararları ve milli çıkarlara vereceği zararları dikkate alarak değerlendirmeler yapmayı esas alırlar ve devlet uygulamaları bu esaslar çerçevesinde olur; olmalıdır. Dolayısıyla, dış politikanın ileriye dönük olarak saptanması, ülkenin o andaki çıkarları ile birlikte, orta ve uzun vadede çıkarlarını da göz önünde bulundurmayı zorunlu kılar.

Nitekim Yunanlı gazeteci Ligeros (2010: 2.)’un da vurguladığı gibi; “Uluslararası politikada önemli olan söylenenler değil, yapılanlardır." Bu bağlamda Türkiye, bulunduğu Avrasya coğrafyasında ekonomik, siyasi ve askeri olarak güçlü pozisyonunu korumak ve caydırıcılı̆̆ını 
muhafaza edebilmek, Türkiye ile KKTC'nin ulusal güvenliklerine zarar gelmesini engellemek maksadıyla, Kıbrıs üzerindeki nüfuzunu artırmakla, KKTC'nin ayrı ve egemen bir devlet olarak varlığını sürdürmesini her şartta ve platformda desteklemekle, Kıbrıs Türk halkının can güvenliği için Türk Silahlı Kuvvetleri'nin adadaki barışı "koruyucu ve temin edici” varlığını devam ettirmekle yükümlüdür.

\section{KAYNAKLAR}

ALASYA Halil Fikret, (1964), Kıbrıs Tarihi ve Kıbrıs'ta Türk Eserleri, Ankara: Türk Kültürünü Araştırma Enstitüsü.

ALASYA Halil Fikret (1981), "Kıbrıs'ta İkili Görüşmeler Notları”, 4. Milletlerarası Türkoloji Kongresi (17-23 Ekim) Bildiriler Kitabı, İstanbul.

ARMAOĞLU Fahir (1983), “Kıbrıs: Akdeniz'in En Önemli Geçidi”, Tercüman, 17-19 Aralık, s.4-5.

ART Robert J., WALTZ Kenneth N., (1971), The Use of Force, Boston: Little Brown And Company.

ATUN Ali Fikret (2011), “Türkiye'nin Ulusal Güvenliği Açısından Kıbrıs'ın Jeopolitik ve Jeostratejik Önemi”, Kıbrıs Mektubu Dergisi, Mart-Nisan, s.4-12.

BRYZA Mattthew J., (2013), "Eastern Mediterranean Natural Gas: Potential For Historic Breakthroughs Among Israel, Turkey, And Cyprus", Turkish Policy Quarterly, C.12, S.3, s.35-44.

ÇÖREKÇİ Ahmet, (2001), "Milli Güvenlik Kurulu'ndan İstenen Yeni Rol”, Ulusal Strateji, S.44, Ocak-Şubat, s.40-51.

GÜRDENİ Cem, (2007), “Türkiye'nin Akdeniz ve Karadeniz'de Deniz Güvenliğine Katkıları", Güvenliğin Yeni Boyutları ve Uluslararası Örgütler, Dördüncü Uluslar arası Sempozyum Bildirileri (İstanbul, 31 Mayıs-01 Haziran 2007), SAREM, s.277-283, Ankara.

HILL George, (1949), A History of Cyprus, Volume I, London: Cambridge University Press.

KANTARCI Şenol, (2004), "Kıbrıs'ta 70 Bin Kişilik Yeni Bir Türk Askeri Üssü Kurulmalı", 2023 Dergisi, S.36, s.37-41.

KESER Ulvi, (2007), “Avrupa Birliği Sürecinde Kıbrıs’ın Hukuki Durumu ve Kıbrıs Tarihine Kesitsel Bir Bakış", SAREM Stratejik Araştırmalar Dergisi, S.9, Şubat, s.130-144.

KESER Ulvi, (Yay.Haz.), (2012), Mare Nostrum Adalar Denizi'nden Kıbrıs'a: Akdeniz ve Sorunlar, Ankara: AKAUM Yayını.

KUTLAY Mustafa, (2012), “Güney Kıbrıs'ın Petrol Arama Hamlesi: Kıbrıs Sorununu Denize Taşıma Stratejisi”, USAK (Uluslararası Stratejik Araştırmalar Kurumu), 12 Şubat; (http://www.usak.org.tr/myazdir.asp?id=2327) (Erişim tarihi: 15 Aralık 2017) 
ULUSAL GÜVENLİK BAĞLAMINDA KIBRIS: JEOSTRATEJİK/JEOEKONOMİK ÖNEM VE GELIŞMELER - Dr. Pınar AKARÇAY - Dr. Gökhan AK

LIGEROS Stavro, (2010), "Milli Güvenlik İçin SOS", Kosmos Tu Ependiti Gazetesi, 10 Temmuz, s.2.

ÖZMEN Süleyman, (2007), “Ulusal Güvenlik Boyutunda Kıbrıs'ın Jeostratejik ve Jeopolitik Önemi", Silahlı Kuvvetler Dergisi, S.391, Ocak, s.4-23.

ÖZTÜRK Osman Metin, (2004), "Kıbrıs Sorununda Perde Arkası”, 2023 Dergisi, S.36, s.5258.

PARKER Robin, (1962), Aphrodite's Realm, Lefkoşa: Zavallis Press.

PAZARCI Hüseyin, (2009), Uluslararası Hukuk, g.g.8.b., Ankara: Turhan Kitapevi.

SANDER Oral, (2007), Siyasi Tarih: 1918-1994, 16.b., Ankara: İmge Kitapevi.

TESSAM, (2008), Kıbrıs'ın Jeostratejik ve Jeopolitik Önemi, İstanbul: TESSAM Kültür Yayınları.

TORUMTAY Necip, (1998), Kıbrıs Sempozyumu: Bildiriler, Soru-Cevaplar, Katkılar ve Konuşma Metinleri (1-2 Aralık 1997), İstanbul: Harp Akademileri Basımevi, s.15-21.

TÜRSAN Nurettin, (1987), Yunan Sorunu, 3.b., Ankara: Genelkurmay ATASE Yayını. 